J. Dairy Sci. 91:3501-3511

doi:10.3168/jds.2007-0967

(c) American Dairy Science Association, 2008.

\title{
Comparison of Red Clover and Ryegrass Silage for Dry Cows and Influence on Subsequent Lactation Performance
}

\author{
J. M. Moorby, ${ }^{1}{ }^{1}$ P. H. Robinson, $†$ W. J. Fisher, ${ }^{*}$ and R. T. Evans* \\ *Institute of Grassland and Environmental Research, Aberystwyth, SY23 3EB United Kingdom \\ †Department of Animal Science, University of California, Davis 95616-8521
}

\begin{abstract}
The objective of this study was to investigate the use of red clover (RC) silage as a forage for dry dairy cows, primarily relative to its impact on tissue mobilization and repletion during the transition period and performance during the first $10 \mathrm{wk}$ of lactation. Forty multiparous lactating Holstein-Friesian dairy cows were divided into 2 paired groups at $70 \mathrm{~d}$ before predicted calving dates; a subset $(n=8)$ of the cows were used for $\mathrm{N}$ and $\mathrm{P}$ balance measurements twice during the study. From the start of the experiment until $4 \mathrm{wk}$ before predicted calving date all cows were offered ad libitum access to a ryegrass (RG) silage with no concentrate. At 4 wk before predicted calving date, one group of cows remained on the same diet, and the other group was changed to a diet of ad libitum access to RC silage. There was no difference in feed intakes, but CP intake was higher in cows fed $\mathrm{RC}$ silage, whereas $\mathrm{ME}$ intake was higher in cows fed RG silage. Cows fed RG silage gained more weight over the last $4 \mathrm{wk}$ of the dry period (DP) than those fed RC silage, but there was no treatment effect on BCS. During the DP fecal N excretion was higher for cows fed RC silage, and there were no treatment differences in urine $\mathrm{N}$ excretion or overall $\mathrm{N}$ balance. At birth, calves from cows fed the $\mathrm{RC}$ silage were heavier. After calving, all cows were offered the same diet of ad libitum access to the same RG silage and a standard lactation concentrate. During the first 10 wk of lactation there was no difference in feed intake between the 2 previous treatment groups, and feed intake reached a maximum at approximately 4 wk of lactation. Cows on the RG treatment during the DP gained more longissimus dorsi muscle depth during the DP and retained it during early lactation. Mobilization of this muscle occurred before calving, indicating repartitioning of amino acids to other body tissues. There were no carryover effects of DP treatment on apparent partitioning of $\mathrm{N}$ from diet to milk, urine, or
\end{abstract}

\footnotetext{
Received December 20, 2007.

Accepted May 16, 2008.

${ }^{1}$ Corresponding author: jon.moorby@aber.ac.uk
}

feces at wk 3 of lactation. Feeding RC silage during the DP had almost no impact on subsequent performance of dairy cows in early lactation, probably because the 2 silages were nutritionally very similar.

Key words: dry period, nitrogen balance, red clover silage, tissue mobilization

\section{INTRODUCTION}

Several recent studies have demonstrated benefits of feeding a good quality dry period (DP) diet on subsequent lactation performance of dairy cows (Van Saun et al., 1993; Moorby et al., 1996; Tesfa et al., 1999). However, many dairy farmers in the United Kingdom are reluctant to feed good quality grass silage to dry cows because they believe this can lead to overconditioned cows at calving. It is well known that DMI decreases in the final 1 to 2 wk before calving, and increasing diet nutrient density may help maintain energy intake during this period (Grummer, 1995), although using grain to do this does not necessarily improve subsequent milk production (VandeHaar et al., 1999). Grummer (1995) noted a positive correlation between DMI shortly before calving and DMI 3 wk after calving. Dewhurst et al. (2000) noted a similar effect, although others have reported the reverse for some diet combinations (Tesfa et al., 1999; Holcomb et al., 2001; Douglas et al., 2006). During the close-up DP requirements for mammary tissue development, fetal calf growth, and colostrum formation are high (Bell, 1995). Body protein reserves, in the form of peripheral tissues (Bell et al., 2000), may be mobilized before calving if the dietary protein supply is insufficient to meet these requirements (Moorby et al., 2000; Moorby et al., 2002b), but the timing of such tissue mobilization is not clear. Maintaining high DMI, although not necessarily high energy intake, during the close-up DP may help promote high DMI in early lactation, reducing prepartum tissue mobilization and enabling better intakes in the early lactation period. Red clover (RC; Trifolium pratense) silage has been shown to have high intake potential in dairy cows (Bertilsson and Murphy, 2003; Dewhurst et al., 2003a,b), and although digestibility tends to be lower than that 
of grass silage, it may offer a way of maintaining DMI during late gestation.

The objective of this study was to investigate the use of RC silage as a forage-only feed for dry cows, compared with the more conventional ryegrass (RG; Lolium perenne) silage. Effects of use of RC silage on tissue mobilization and repletion during the transition period and subsequent performance of dairy cows during the first $10 \mathrm{wk}$ of lactation was the main focus of the study. Frequent measurements of body parameters in late gestation and early lactation were made to identify the timing of tissue mobilization during the transition period.

\section{MATERIALS AND METHODS}

\section{Cows and Management}

All procedures used in this experiment were licensed and regulated by the UK Home Office under the Animals (Scientific Procedures) Act of 1986. Forty multiparous lactating Holstein-Friesian dairy cows were divided into 2 paired groups balanced for parity and previous lactation performance at $70 \mathrm{~d}$ before predicted calving dates. From within the 2 groups, cows of each pair were assigned at random to each of the experimental treatments. Cows were kept in a free-stall barn with free access to fresh water at all times, apart from a subset of the animals $(n=8)$ that were transferred to a metabolism unit for $\mathrm{N}$ balance measurements twice during the experiment.

From the start of the experiment until 4 wk before predicted calving date, all cows were offered ad libitum access to a standard RG silage (Table 1 ) with no concentrate feed supplement and were milked twice daily at 0500 and 1500 h. Forages were offered through forage intake control feeders (Insentec B.V., Marknesse, the Netherlands) to allow automatic recording of ad libitum feed intakes. From 1 wk before drying off at $56 \mathrm{~d}$ before predicted calving date, all cows were milked once daily at $1500 \mathrm{~h}$. At 4 wk before predicted calving date, 1 of the 2 groups of cows remained on the same diet of ad libitum access to RC silage and the other group was changed to a diet of ad libitum access of RC (cv. Milvus) silage (Table 1). Ryegrass silage was prepared from a first cut sward consisting predominantly of perennial $\mathrm{RG}$ and ensiled in a bunker silo. The RC silage was prepared as big round bales and used in a 2:1 mix of first and second cut silages (i.e., 2 bales of first cut and 1 bale of second cut). Both crops were ensiled with an inoculant designed to supply 1 million cfu of Lactobacillus plantarum (strain MTD1) per gram of forage (Ecosyl, Ecosyl Products Ltd., Stokesley, UK), applied at the manufacturer's recommended rates of $1.5 \mathrm{~L} / \mathrm{t}$ of crop. The RC silage mix was prepared daily in a mixer wagon [Richard Keenan (UK) Ltd., Kenilworth, UK] fitted with a chopping mixing auger.

Shortly before calving (i.e., 24 to $48 \mathrm{~h}$ ), as judged by dairy staff, cows were moved to a straw-bedded pen and maintained on their allocated diet, where they remained with the calf until 24 to $48 \mathrm{~h}$ after calving.

After calving, all cows were offered the same diet of ad libitum access to a first-cut RG silage and a standard lactation concentrate (Table 1). The amount of concentrates offered was gradually increased during the first week of lactation to the full allowance of 6 $\mathrm{kg} / \mathrm{d}$, which was then maintained for the duration of the experiment. The concentrate feed (Wynnstay Dairy 22 HC Nuts; Wynnstay Group PLC, Llansantffraid, Powys, UK) was commercially produced and contained (declared in descending order of weight): wheat, beans, low glucosinolate rapeseed meal, corn distillers' dark grains, cane molasses, high protein soy, palm kernel expellers, vegetable oil, calcium carbonate, magnesium oxide, vitamin and mineral mix (declared contents of finished feed, vitamin A: $10,000 \mathrm{IU} / \mathrm{kg}$, vitamin $\mathrm{D}_{3}$ : $2000 \mathrm{IU} / \mathrm{kg}$, a-tocopherol: $50 \mathrm{IU} / \mathrm{kg}$, sodium selenite: $0.52 \mathrm{mg} / \mathrm{kg}$, and cupric sulfate: $39 \mathrm{mg} / \mathrm{kg}$ ), and dicalcium phosphate.

\section{Measurements and Sample Analysis}

All cows were weighed and scored for body condition (on a 0 to 5 scale; Mulvany, 1977) at the tail head and loin at the same time and day each week until 2 wk before calving. At the same time, depth of muscle longissimus dorsi was measured using real-time ultrasound (Moorby et al., 2002a). From approximately 2 wk before calving, cows were weighed and BCS and longissimus dorsi depth was measured each Monday, Wednesday, and Friday. Following calving, BW was recorded each day following the morning milking until the end of the experiment, whereas BCS and longissimus dorsi depth were measured weekly at the same time and day of each week.

Before the experiment, core samples were taken from the RC silage bunker and a small number of RC silage bales. These samples were pooled and analyzed immediately for minerals to calculate the dietary cationanion difference. During the experiment, feed samples were collected as offered to the cows in the free-stall barn twice weekly and pooled monthly. All samples were stored frozen until analysis. Procedures for handling and analyzing these samples were as outlined by Jaurena et al. (2005a) and Lee et al. (2003). Forage Na and $\mathrm{K}$ concentrations were determined following ignition of the organic matter in a muffle furnace at $550^{\circ} \mathrm{C}$ for $16 \mathrm{~h}$ and dissolution in $25 \% \mathrm{HCl}$, with extracts ana- 
Table 1. Nutritional composition of the feeds offered during the experiment ${ }^{1}$

\begin{tabular}{lccc}
\hline & \multicolumn{2}{c}{ Silage } & \\
\cline { 2 - 3 } Item & Red clover & Ryegrass & Concentrate \\
\hline $\mathrm{DM}{ }^{2} \%$ & 24.4 & 30.2 & 86.1 \\
$\mathrm{OM}$ & 88.1 & 91.3 & 91.8 \\
$\mathrm{CP}(\mathrm{N} \times 6.25)$ & 18.7 & 17.8 & 23.4 \\
Ammonia-N & 0.38 & 0.32 & - \\
Water-soluble carbohydrates & 1.5 & 6.2 & 10.8 \\
NDF & 46.5 & 47.5 & 19.2 \\
Starch & - & - & 33.1 \\
Acid hydrolysis ether extract & - & - & 3.9 \\
ME, Mcal/kg of DM & - & 4.05 & - \\
pH & 4.41 & 10.8 & - \\
Lactic acid & 7.9 & 1.50 & - \\
Acetic acid & 1.2 & 0.09 & - \\
Propionic acid & 0.08 & 0.26 & - \\
$n$-Butyric acid & 0.34 & ND & - \\
Daidzein & 0.04 & ND & - \\
Genistein & 0.07 & ND & - \\
Biochanin A & 0.15 & ND & - \\
Formononetin & 0.36 & & - \\
\hline
\end{tabular}

${ }^{1}$ Ryegrass silage was offered from before drying off until the end of the experiment, red clover silage was offered during the dry period, and the concentrate was offered during the lactation period (figures in \% DM unless otherwise stated).

${ }^{2}$ Determined by freeze drying.

${ }^{3}$ Not detected.

lyzed using a Corning 410 flame photometer (Corning Ltd., Halstead, UK). Chloride and S concentrations in forage were determined by method 19 and method 72 in The Analysis of Agricultural Materials (Ministry of Agriculture Fisheries and Food, 1986). Forage dietary cation-anion difference was calculated in $\mathrm{mEq} / 100 \mathrm{~g}$ of $\mathrm{DM}$ as $[\mathrm{Na}+\mathrm{K}]-[\mathrm{Cl}+\mathrm{S}]$ (Tucker et al., 1992). Forage isoflavanoid concentrations were determined by HPLC following a water/methanol extraction. Approximately $0.05 \mathrm{~g}$ of freeze-dried, ground, and mixed material was incubated in $5 \mathrm{~mL}$ of water at $37^{\circ} \mathrm{C}$ for $4 \mathrm{~h}$ with occasional mixing. The sample was centrifuged for $10 \mathrm{~min}$ at approximately $1,500 \times g$, and the supernatant was decanted and kept. The pellet was resuspended in 2 $\mathrm{mL}$ of deionized water, then recentrifuged, the supernatant again being decanted and kept. The pellet was then resuspended and recentrifuged in $10 \mathrm{~mL}$ of $100 \%$ methanol, and then again in $5 \mathrm{~mL}$ of $100 \%$ methanol, with supernatants being decanted and kept; the pellet was finally discarded. All decanted supernatants were mixed together and filtered to remove any particles using Fisherbrand QL100 filter paper (Fisher Scientific UK Ltd., Loughborough, UK). Methanol was removed from the samples using a rotary evaporator, and the volume was made to up $10 \mathrm{~mL}$ with water. A $4-\mathrm{mL}$ aliquot of this was loaded onto a Sep-Pak Vac RC C18 cartridge (Waters Ltd., Elstree, Herts., UK) and eluted with $4 \mathrm{~mL}$ of $100 \%$ methanol. This was then dried down on a hotplate $\left(50^{\circ} \mathrm{C}\right)$ under a gentle air draft. The dried sample was dissolved in $480 \mu \mathrm{L}$ of $70 \%$ methanol. A $60-\mu \mathrm{L}$ aliquot of this was injected onto the HPLC system (composed of a Waters 515 pump coupled to a Waters 996 photodiode detector array) fitted with a Waters C18 Radial-Pak cartridge $(8 \mathrm{~mm} \times 100 \mathrm{~mm})$ in a Waters radial compression module. The sample was separated using eluents of (A) $5 \%$ acetic acid and (B) $100 \%$ methanol running at a flow rate of $2 \mathrm{~mL} / \mathrm{min}$ on a gradient of 0 to $100 \%$ methanol over $50 \mathrm{~min}$.

Following calving, milk yields were recorded automatically by the parlor computer at each milking, and from the second week of lactation milk samples were collected from 2 consecutive milkings each week for determination of fat, protein, and lactose by near infrared analysis (National Milk Records, Yeovil, Somerset, UK). Blood samples were collected from the tail vessels at wk 1, 3, 5, 7, and 9 of lactation into evacuated collection tubes (Vacuette, Greiner Bio-One Ltd., Stonehouse, Glos., UK) containing heparin (for plasma proteins, urea, and BHBA analysis) and oxalate/fluorate (for glucose and NEFA analysis). Tubes of blood were immediately placed in ice, and within $90 \mathrm{~min}$, the blood samples were centrifuged at $1,700 \times g$ for $25 \mathrm{~min}$ at $4^{\circ} \mathrm{C}$, and plasma decanted into 5 separate microcentrifuge tubes for storage at $-18^{\circ} \mathrm{C}$. Plasma was analyzed using discrete analyzer methods for total protein (Sigma kit no. 541-2; Sigma-Aldrich Company Ltd., Poole, UK), albumin (Sigma kit no. 621-3P), urea (Sigma kit no. 66), glucose (Sigma kit no. 16-UV), and B-hydroxybutyrate 
(Sigma kit no. 310A). Plasma globulins concentration was calculated as the difference between plasma total protein and albumin concentrations.

Eight cows, 4 from each DP treatment group, were transferred to a metabolism unit for $\mathrm{N}$ and $\mathrm{P}$ balance measurements at approximately $3 \mathrm{wk}$ before predicted calving date and at 3 wk after calving. These cows were chosen on the basis of their calving date to achieve a tight calving group and remained on their allocated treatments throughout the measurements. Forages continued to be offered ad libitum, and orts were collected to allow calculation of feed intake. After a 1-wk adjustment period, externally applied urine and feces separators were used to collect total outputs of excreta from the cows for $8 \mathrm{~d}$ during the DP and $6 \mathrm{~d}$ during lactation. During lactation, milk samples were also collected. Subsamples of feed, excreta, and milk were collected and analyzed as described previously (Moorby et al., 2006). Nitrogen balance was calculated as the difference between total $\mathrm{N}$ intake (in feed) and $\mathrm{N}$ outputs (in excreta and, when lactating, milk). Apparent whole-tract diet digestibility was also measured at these times as the difference in intake and output of $\mathrm{DM}, \mathrm{OM}, \mathrm{N}$, and $\mathrm{NDF}$, and these values were used to calculate intakes of digestible diet components for all cows on the appropriate treatments. Diet ME (Mcal/ $\mathrm{kg}$ ) density was calculated as $3.7 \times$ digestibility of $\mathrm{OM}$ expressed as a proportion (g/g) of the DM (Agricultural and Food Research Council, 1993).

\section{Statistical Analysis}

To determine the shape of the response of $\mathrm{BW}$ to treatment, individual cow data were mean centered (i.e., individual weights minus the mean of all weights of each cow) and were added to the treatment mean BW. Individual cow data were then smoothed using a logistic curve with the NLINFIT procedure of Matlab (R2007a, The Mathworks, Cambridge, UK) as

$$
\mathrm{LW}=\mathrm{a} /\left(1+\mathrm{b} \times \mathrm{e}^{-\mathrm{c} \times \text { Day before calving }}\right),
$$

where $a, b$, and c are shape parameters.

Subsequent statistical analysis of data, as described below, was completed using Genstat (Payne et al., 2007).

Individual BW changes over the DP treatment period were calculated as the difference between fitted weights computed from each cow's individually fitted curve on the first and last precalving actual weighing days during the 4 -wk period before calving. Data collected from a single time point (i.e., diet digestibility and $\mathrm{N}$ partitioning data) and data averaged among measurements during the DP (i.e., feed intake, BW change) were analyzed by ANOVA using DP treatment as the treatment structure, and no blocking. Precalving $\mathrm{BW}$ and $\mathrm{BW}$ change data were analyzed as above using modeled initial BW data as covariates. Body condition scores and ultrasound scan depth data collected during the DP and during lactation were averaged for each cow in each of these 2 periods and analyzed as above using cow parity as a covariate. In addition, treatment mean longissimus dorsi depth data collected throughout the experiment were analyzed by quartic regression with treatment grouping to allow effects of DP treatment on model parameters to be assessed. Calf birth weights were analyzed by REML analysis because of unequal representation of bull and heifer calves, using individual cows as a random term, and dry period treatment $x$ calf sex as a fixed term.

Data collected during lactation (i.e., milk yields and composition, intakes, BW, and body parameters) were analyzed by repeated measures ANOVA using data that were averaged for each week of lactation, using DP treatment and week of lactation (and their interaction) as treatment effects and no blocking. Plasma metabolite data were also analyzed by repeated measures ANOVA of data from each sampling point. Statistical significance was declared if $P<0.05$.

\section{RESULTS}

Of the 40 cows that started the experiment, 1 cow from each treatment was removed from the experiment; 1 cow calved much later than predicted; and 1 cow was culled due to injury. Another cow calved twins, and although the cow completed the experiment, data from her and the other 2 cows were excluded from analyses.

\section{Feed Composition}

The RC and RG silages fed during the DP differed in their DM contents, and concentrations of OM, ammonia- $\mathrm{N}$, and residual water-soluble carbohydrates (Table 1). The $\mathrm{CP}$ concentration of the $\mathrm{RC}$ silage was only slightly higher than that of the RG silage, whereas the NDF concentrations of the 2 silages were similar. For samples of the 2 silages collected before the start of the experiment, mean concentrations of $\mathrm{Na}, \mathrm{K}, \mathrm{Cl}$, and $\mathrm{S}$ were $0.48,2.65,0.75$, and $0.17 \% \mathrm{DM}$ for $\mathrm{RC}$ silage and $0.68,2.88,0.85$, and $0.28 \% \mathrm{DM}$ for RG silage, respectively, leading to calculated dietary cation-anion difference values of +57 and $+62 \mathrm{mEq} / 100 \mathrm{~g}$ of DM. Silage isoflavanoid contents were very different, with no detectable quantities of daidzein, genistein, biochanin $\mathrm{A}$, or formononetion in RC silage, but there were relatively high concentrations, particularly of formononetin, in RC silage. 
The mean ME density of the lactation diet, as measured at wk 3 of lactation, was $2.45 \mathrm{Mcal} / \mathrm{kg}$ of DM.

\section{Dry Period}

There was no effect of DP treatment on deviation from calving date predicted from breeding records, assuming a standard gestation length of $280 \mathrm{~d}$. Actual gestation lengths varied from this by a mean of 3.6 and $5.1 \mathrm{~d}$ [standard error of differences of means (SED) $=1.93, \mathrm{NS}]$ for cows offered the RC and RG silages, respectively.

During the DP, there was no difference in intakes of DM, OM, or NDF (Table 2), but CP intake was higher $(P=0.03)$ in cows fed RC silage. However, the digestibility of DM, OM, N, and NDF were all higher $(P<$ 0.001 ) in the $R G$ silage compared with the RC silage. Intakes of both treatment groups were relatively stable throughout the DP until approximately 2 wk before calving, at which point they started to decline, reaching a minimum of approximately $10 \mathrm{~kg}$ of $\mathrm{DM} / \mathrm{d}$. The $\mathrm{ME}$ density of the diets fed during the $\mathrm{DP}$ was calculated to be 2.17 and $2.58 \mathrm{Mcal} / \mathrm{kg}$ of DM for RC and RG silages, respectively (SED $=0.023, P<0.001$ ), and therefore ME intake was greater $(P<0.001)$ for cows fed the RG silage. At birth, calves were heavier $(P=0.02)$ from cows fed the $\mathrm{RC}$ silage versus those fed the RG silage (Table 2). Bull calves were also heavier than heifer calves (42.7 versus $40.6 \mathrm{~kg}, \mathrm{SED}=1.03, P=0.033$ ), and there was no DP treatment $\times$ calf sex interaction. Cows in both treatment groups gained weight until shortly before calving, although the rate of BW gain slowed toward the end of gestation (Figure 1). Cows fed RG silage gained more weight over the last $4 \mathrm{wk}$ of the DP so that their mean precalving weight was $20 \mathrm{~kg}$ heavier than that of RC-fed cows. However, there were no differences in DP mean BCS or longissimus dorsi scan depths between treatments.

For cows that underwent $\mathrm{N}$ and $\mathrm{P}$ balance measurements, those fed RC silage consumed more $(P=0.01)$ $\mathrm{N}$ than those fed RG silage (Table 3). However, fecal $\mathrm{N}$ excretion was greater $(P<0.001)$ for cows fed RC silage, and there were no treatment differences in urine $\mathrm{N}$ excretion or overall $\mathrm{N}$ balance. Similarly, although $\mathrm{P}$ intakes were greater $(P<0.001)$ for cows fed the RG silage, fecal $\mathrm{P}$ excretion was also greater $(P<0.001)$ and overall $\mathrm{P}$ balance was essentially the same for both treatments. Daily rates of urine excretion of allantoin, uric acid, 3-methyl histidine, and creatinine were similar for both treatment groups.

Table 2. Mean dry period forage DMI and diet apparent whole-tract digestibilities of dairy cows offered ryegrass silage or red clover silage $\left(n=20\right.$ per treatment) during the last 4 wk of the dry period ${ }^{1}$

\begin{tabular}{lcccc}
\hline & \multicolumn{2}{c}{ Dry period treatment } & & \\
\cline { 2 - 3 } Item & Red clover & Ryegrass & SED & P-value \\
\hline Forage intake, kg/d & & & & \\
DM & 13.3 & 12.8 & 0.47 & 0.34 \\
OM & 11.7 & 11.7 & 0.41 & 0.98 \\
CP & 2.5 & 2.3 & 0.08 & 0.03 \\
NDF & 6.2 & 6.1 & 0.22 & 0.71 \\
ME intake, Mcal/d & 28.8 & 33.2 & 1.08 & $<0.001$ \\
Nutrient digestibility, \% & & & & \\
DM & 61.9 & 73.2 & 0.65 & $<0.001$ \\
OM & 65.4 & 74.8 & 0.63 & $<0.001$ \\
N & 60.8 & 66.8 & 0.61 & $<0.001$ \\
NDF & 65.7 & 75.6 & 1.31 & $<0.001$ \\
DOMD & 57.9 & 68.9 & 0.60 & $<0.001$ \\
Precalving BW, ${ }^{3}$ kg & 738 & 758 & 1.75 & $<0.001$ \\
Precalving treatment BW change, $\mathrm{kg}$ & 15.4 & 35.0 & 1.75 & $<0.001$ \\
Mean longissimus dorsi scan depth, ${ }^{4} \mathrm{~mm}$ & 42.1 & 43.2 & 1.24 & 0.40 \\
Max. longissimus dorsi scan depth, $\mathrm{mm}$ & 46.1 & 47.5 & 1.43 & 0.32 \\
Tail BCS ${ }^{4}$ & 2.6 & 2.5 & 0.07 & 0.25 \\
Loin BCS & 2.5 & 2.5 & 0.06 & 0.42 \\
Calf birth weight, ${ }^{5}$ kg & 42.5 & 40.8 & 1.03 & 0.02 \\
\hline
\end{tabular}

${ }^{1}$ Mean BW and BW change from 4 wk before calving until calving, scan depth over the same period, and maximum scan depth recorded, tail and loin BCS, and mean calf birth weights.

${ }^{2}$ Digestibility of the OM expressed as a proportion of DM in the sample.

${ }^{3}$ Precalving BW and BW change data were analyzed using modeled weight at start of imposition of dry period treatments as a covariate.

${ }^{4}$ Scan depth and BCS data were analyzed using each cow's parity as a covariate.

${ }^{5}$ Calf birth weight data were analyzed using sire as a covariate. 
Table 3. Nitrogen intake and output, whole-body $\mathrm{N}$ partitioning, and daily excretion rates of purine derivatives, 3-methylhistidine, and creatinine of dry dairy cows, at approximately $3 \mathrm{wk}$ before calving, offered grass silage or red clover silage

\begin{tabular}{|c|c|c|c|c|}
\hline \multirow[b]{2}{*}{ Item } & \multicolumn{2}{|c|}{ Dry period treatment } & \multirow[b]{2}{*}{ SED } & \multirow[b]{2}{*}{$P$-value } \\
\hline & Red clover & Ryegrass & & \\
\hline $\mathrm{N}$ intake, $\mathrm{g} / \mathrm{d}$ & 376 & 349 & 6.6 & 0.01 \\
\hline \multicolumn{5}{|l|}{$\mathrm{N}$ output, $\mathrm{g} / \mathrm{d}$} \\
\hline Urine & 171 & 174 & 6.9 & 0.74 \\
\hline Feces & 147 & 116 & 3.2 & $<0.001$ \\
\hline $\mathrm{N}$ balance, $\mathrm{g} / \mathrm{d}$ & 57 & 60 & 9.8 & 0.77 \\
\hline $\mathrm{P}$ intake, $\mathrm{g} / \mathrm{d}$ & 32.6 & 43.2 & 1.09 & $<0.001$ \\
\hline \multicolumn{5}{|l|}{$\mathrm{P}$ output, g/d } \\
\hline Urine & 1.5 & 2.2 & 0.28 & 0.05 \\
\hline Feces & 29.8 & 39.0 & 0.61 & $<0.001$ \\
\hline $\mathrm{P}$ balance, $\mathrm{g} / \mathrm{d}$ & 1.4 & 2.0 & 1.39 & 0.66 \\
\hline \multicolumn{5}{|c|}{ Urinary excretion, $\mathrm{mmol} / \mathrm{d}$} \\
\hline Allantoin & 275 & 307 & 86.5 & 0.72 \\
\hline Uric acid & 75 & 32 & 34.3 & 0.26 \\
\hline 3-Methylhistidine & 1.65 & 1.99 & 0.210 & 0.16 \\
\hline Creatinine excretion & 208 & 200 & 67.2 & 0.91 \\
\hline
\end{tabular}

\section{Lactation}

During the first 10 wk of lactation, there was no difference in DMI between the 2 groups of cows previously offered different DP diets (Table 4). Likewise, there were no differences in feed component digestibilities as measured at wk 3 of lactation. Although mean BW during the first $10 \mathrm{wk}$ of lactation was not affected by previous DP treatment, the time $\times$ treatment interaction tended $(P=0.06)$ to be significant. This effect was apparent in the data plot (Figure 2), in which mean BW of the RG-fed cows was greater than that of the $\mathrm{RC}$ group immediately after calving, but dropped to the same level by about $45 \mathrm{~d}$ after calving. Body condition score was likewise unaffected by DP treatment. The mean scan depth of longissimus dorsi tended $(P=0.10)$ to be higher in cows previously offered RG silage during the DP, and there was a time $\times$ treatment interaction $(P=0.03)$. The polynomial regression of scan depth for $\mathrm{RC}$ cows on days relative to parturition was significant $(P<0.001)$, as was the effect of DP treatment $(P=0.01)$ when RG silage treatment data were added to the model (overall $\mathrm{R}^{2}=0.67$ ). All equation parameters in the basal RC model were significant $(P<0.02)$ except for the quartic parameter, but when RG silage cow data were added, only the additional component to the constant was significant $(P<0.001)$, indicating a general similarity in the shape of the curves, with a difference in overall muscle depth. Muscle depth of both groups of cows increased from the start of the DP and started to decrease before calving (Figure 3). Maximum depths occurred 1 to $2 \mathrm{wk}$ before calving, and minimum depths occurred at approximately 7 wk postcalving. Cows on the RG DP treatment gained more muscle depth during the DP and retained it during early lactation.

There were no main effects of DP treatment on milk yield and composition (Table 5). However, there were interaction effects of DP treatment with stage of lactation on milk fat concentrations $(P<0.001)$ and yields $(P$ $=0.003)$ : cows fed RG silage during the DP had higher milk fat concentrations than cows fed the RC silage for the first 2 to $3 \mathrm{wk}$ of lactation (data not shown).

There were no carryover effects of DP treatment on apparent partitioning of $\mathrm{N}$ or $\mathrm{P}$ from diet to milk, urine, or feces at wk 3 of lactation (Table 6). Whole-

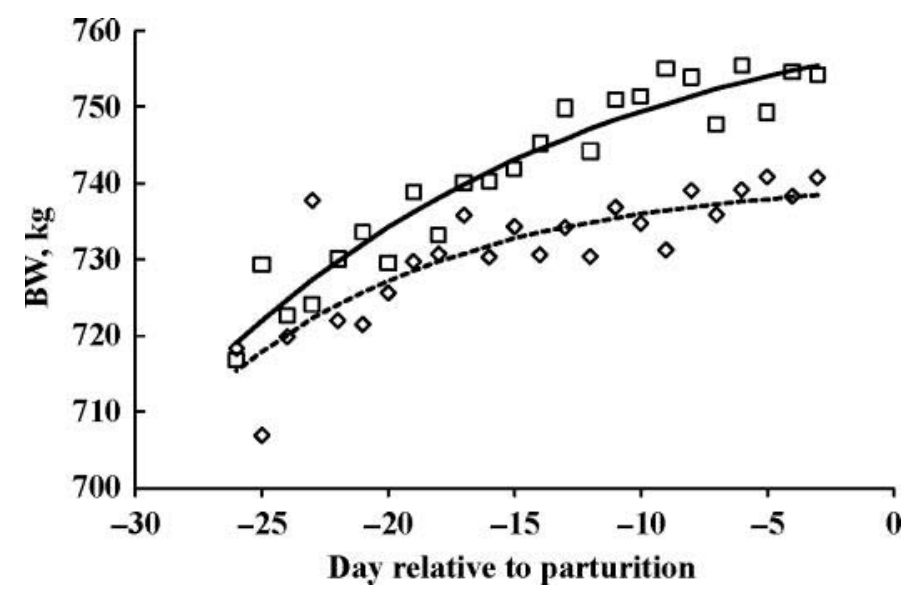

Figure 1. Treatment mean BW over the last 4 wk of the dry period of dairy cows offered red clover $(\diamond)$ or ryegrass $(\square)$ silage. Lines are logistic curves fitted to mean data: red clover, $\mathrm{BW}=740.7 /(1+$ $\left.0.0022 \times \mathrm{e}^{-0.018 \times \text { day before calving }}\right), P<0.001, \mathrm{R}^{2}=0.65$; ryegrass, $\mathrm{BW}=$ $765.4 /\left(1+0.0106 \times \mathrm{e}^{-0.069 \times \text { day before calving }}\right), P<0.001, \mathrm{R}^{2}=0.91$. 
Table 4. Mean feed intake, BW, BCS, and longissimus dorsi scan depths during the first 10 wk of lactation, and feed apparent whole-tract digestibilities measured at wk 3 of lactation, of cows previously offered grass silage or red clover silage

\begin{tabular}{|c|c|c|c|c|c|c|}
\hline \multirow[b]{2}{*}{ Item } & \multicolumn{2}{|c|}{ Dry period treatment } & \multirow[b]{2}{*}{$\mathrm{SED}^{1}$} & \multicolumn{3}{|c|}{$P$-value ${ }^{2}$} \\
\hline & Red clover & Ryegrass & & DP Trt & Time & Int. \\
\hline \multicolumn{7}{|l|}{ Feed intake, kg/d } \\
\hline Forage DM & 12.2 & 12.0 & 0.49 & 0.60 & $<0.001$ & 0.17 \\
\hline Total DM & 17.2 & 17.0 & 0.50 & 0.60 & $<0.001$ & 0.16 \\
\hline \multicolumn{7}{|l|}{ Feed digestibility, \% } \\
\hline $\mathrm{DM}$ & 73.0 & 73.3 & 0.88 & 0.76 & - & - \\
\hline NDF & 67.0 & 69.6 & 1.86 & 0.21 & - & - \\
\hline $\mathrm{DOMD}^{3}$ & 66.6 & 65.9 & 0.93 & 0.47 & - & - \\
\hline $\mathrm{BW}, \mathrm{kg}$ & 654 & 663 & 18.9 & 0.61 & 0.03 & 0.06 \\
\hline $\begin{array}{l}\text { Mean longissimus dorsi } \\
\text { scan depth, mm }\end{array}$ & 39.1 & 41.4 & 1.66 & 0.10 & 0.01 & 0.03 \\
\hline Tail BCS & 2.48 & 2.51 & 0.101 & 0.74 & 0.01 & 0.26 \\
\hline Loin BCS & 2.38 & 2.39 & 0.098 & 0.84 & 0.06 & 0.40 \\
\hline
\end{tabular}

${ }^{1}$ Interaction standard error of the differences of the means.

${ }^{2} \mathrm{DP}$ Trt $=$ dry period treatment effect; Time $=$ wk of lactation effect; Int. $=$ Time $\times$ Trt interaction effect.

${ }^{3}$ Digestibility of the OM expressed as a proportion of DM.

body $\mathrm{N}$ and $\mathrm{P}$ balances were approximately zero at wk 3 of lactation. There were no carryover effects of DP treatment on urinary excretions of purine derivatives, 3-methylhistidine, and creatinine.

During the lactation phase of the experiment, plasma total protein concentrations tended to be higher in cows previously fed the RG silage DP diet, but none of the other plasma metabolites measured were affected by DP treatment. Grand mean plasma B-hydroxybutyrate concentration was $0.74 \mathrm{~m} M$. There were DP treatment $\times$ time interactions on total protein $(P=0.02)$, globulins $(P=0.04)$, and NEFA $(P=0.02)$ concentrations. In particular, NEFA concentrations of cows fed the RC

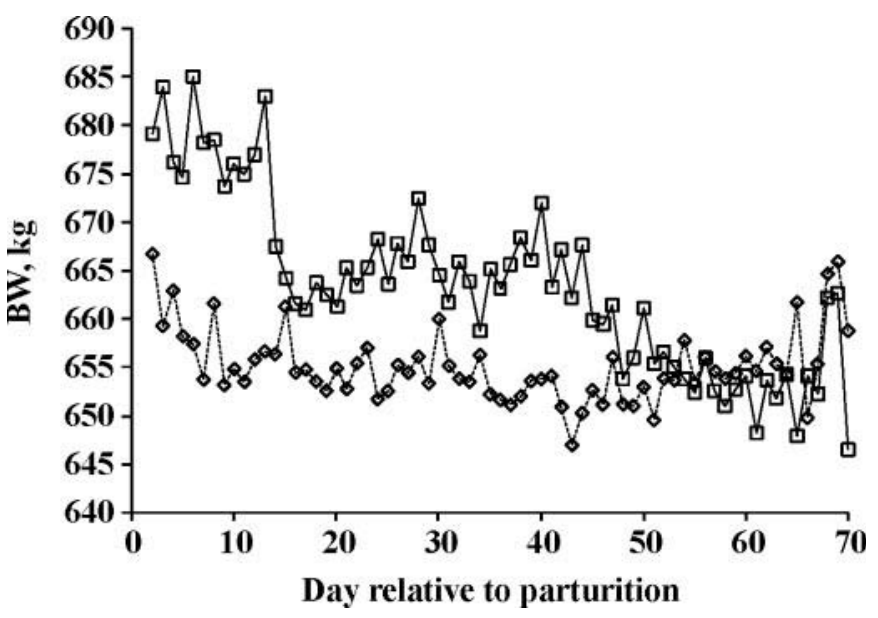

Figure 2. Mean BW, for the first 10 wk of lactation, of dairy cows previously offered red clover $(\diamond)$ or ryegrass $(\square)$ silage for the last 4 wk of the dry period. Mean pooled standard error $=27.2 \mathrm{~kg}$. silage prepartum were higher in early lactation and fell to concentrations similar to those of the RG diet fed cows at approximately wk 3 of lactation, whereas the NEFA concentrations of the RG cows remained relatively constant over the measurement period (data not shown).

\section{DISCUSSION}

\section{Dry Period Responses}

The overall chemical composition of the 2 silages offered during the DP was more similar than expected, and although the $\mathrm{CP}$ concentration of the $\mathrm{RC}$ silage was similar to that produced previously at our institute (e.g., Dewhurst et al., 2003b), that of the RG silage was greater than expected.

Previous work has reported increased DMI of legume silages compared with grass silages in lactating cows (Thomas et al., 1985; Bertilsson and Murphy, 2003; Dewhurst et al., 2003b), and we originally hypothesized that use of RC silage may hold intakes higher during the late DP. However, we found no differences in mean DMI between the 2 groups of dry cows, or in the shape of the drop in feed intake as calving approached, and therefore our hypothesis proved false.

Although ME intake of the 2 silage diets differed during the DP, microbial $\mathrm{N}$ outflow from the rumen, as indicated by rates of urinary purine derivative excretion (Johnson et al., 1998; González-Ronquillo et al., 2004) in the cows at approximately 3 wk before calving, was unaffected by dietary treatment during the DP. This indicates similarities in the rumen fermentation of the 
Table 5. Mean milk yields and composition during the first $10 \mathrm{wk}$ of lactation of dairy cows previously fed dry period diets of red clover silage or ryegrass silage

\begin{tabular}{|c|c|c|c|c|c|c|}
\hline \multirow[b]{2}{*}{ Item } & \multicolumn{2}{|c|}{ Dry period treatment } & \multirow[b]{2}{*}{$\mathrm{SED}^{1}$} & \multicolumn{3}{|c|}{$P$-value ${ }^{2}$} \\
\hline & Red clover & Ryegrass & & Trt & Time & Int. \\
\hline Fat & 40.5 & 40.7 & 1.59 & 0.87 & 0.22 & 0.001 \\
\hline Protein & 30.9 & 31.7 & 0.70 & 0.19 & $<0.001$ & 0.26 \\
\hline Lactose & 47.6 & 47.8 & 0.43 & 0.72 & 0.005 & 0.87 \\
\hline \multicolumn{7}{|l|}{ Milk constituent yields, g/d } \\
\hline Protein & 1,011 & 1,051 & 35.6 & 0.20 & $<0.001$ & 0.11 \\
\hline Lactose & 1,565 & 1,590 & 68.3 & 0.69 & $<0.001$ & 0.36 \\
\hline
\end{tabular}

${ }^{1}$ Interaction standard error of the differences of the means.

${ }^{2} \mathrm{DP}$ Trt $=$ dry period treatment effect; Time $=$ wk of lactation effect; Int. $=$ Time $\times$ Trt interaction effect.

2 silages, as measured by Dewhurst et al. (2003a), who also measured higher whole tract digestibilities in RG silage compared with RC silage, as in the current study. This suggests more digestion of RG silage in the lower intestine, resulting in higher availability of energy.

One objective of the study was to investigate effects of DP treatment on BW change during the DP, particularly during the period shortly before calving, and therefore the cows were weighed 3 times each week. Daily weighing of the dry cows was not possible, making treatment daily mean values calculated relative to actual calving date very variable because each contained values from different cows. Calculating average weights with more values, for example to give weekly BW means, would have allowed easier comparison between cows on each treatment, but would have also reduced the resolution of the data at a time when rapid BW changes could have been occurring. In addition to this, large variation in the sizes of individual animals meant that BW data had a large amount of variation that was not necessarily related to treatment; the size of the cow was considered to be less important than the change in BW of the cow. Therefore, BW data were considered from $26 \mathrm{~d}$ before calving (when all RC-fed cows had been changed to the RC diet) until $3 \mathrm{~d}$ precalving when many of the cows were moved to calving pens and were modeled using a logistic curve. Cow BW followed this curve over the last 4 wk of gestation and, on both treatments, continued to increase until calving. The steepness of the curves appeared to differ between treatments, presumably due to differences in energy intake, leading to the small but significant differences in BW shortly before calving. This difference in BW was not accompanied by changes in BCS over the same period.

Bell et al. (1995) demonstrated that fetal growth in multiparous Holstein cows is essentially exponential until parturition, and the gravid uterus accretes about
16 to $19 \mathrm{~g}$ of $\mathrm{N} / \mathrm{d}$ between d 250 and 270 of gestation. In the present study, the mean daily $\mathrm{N}$ balance of both groups of cows was more than 3 times this amount at approximately $3 \mathrm{wk}$ before calving. Thus, both DP diets supplied more than enough $\mathrm{N}$ to support fetal development. Despite this, there were effects of treatment on calf birth weight, with cows fed the RC silage producing heavier calves. Gestation length is unlikely to have affected calf birth weight because it was similar for both groups of cows. In common with many legumes, RC contains isoflavanoid compounds that, together with their rumen conversion product equol, act as estrogen analogs (phytoestrogens) that can have physiological effects on the animals that consume them (Thomson, 1975; Austin et al., 1982; Moorby et al., 2004). Rapid uptake of isoflavanoids into peripheral blood circula-

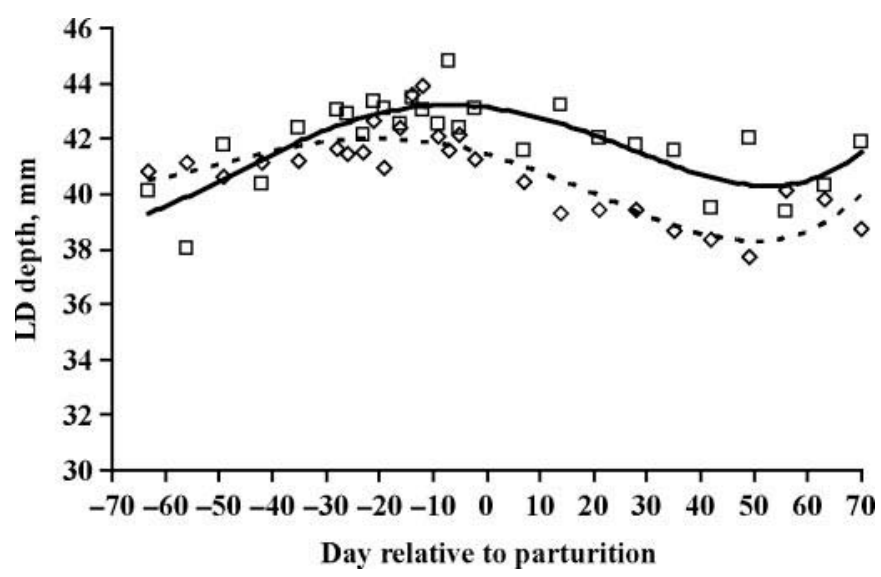

Figure 3. Treatment mean longissimus dorsi (LD) muscle depths (and fitted lines) measured by real-time ultrasonography at the loin region of dairy cows offered red clover $(\diamond, \ldots)$ or ryegrass $(\square,-\longrightarrow)$ silage for the last $4 \mathrm{wk}$ of the dry period. The equations for the fitted lines were: $\mathrm{LD}$ depth $=41.4-0.054 \mathrm{x}-0.0011 \mathrm{x}^{2}+0.00001 \mathrm{x}^{3}+$ $0.00000018 \mathrm{x}^{4}$ for red clover $\left(\mathrm{R}^{2}=0.71\right)$, and $\mathrm{LD}$ depth $=43.1-0.023 \mathrm{x}$ $-0.0016 \mathrm{x}^{2}-0.0000085 \mathrm{x}^{3}+0.00000021 \mathrm{x}^{4}$ for grass silage $\left(\mathrm{R}^{2}=0.66\right)$ where $\mathrm{x}=$ day relative to parturition. 
Table 6. Nitrogen intakes and outputs, whole-body nitrogen and phosphorus partitioning, and daily rates of urinary purine derivative, 3-methylhistidine, and creatinine excretion of lactating dairy cows (at wk 3 of lactation) previously offered red clover silage or ryegrass silage during the dry period

\begin{tabular}{|c|c|c|c|c|}
\hline \multirow[b]{2}{*}{ Item } & \multicolumn{2}{|c|}{ Dry period treatment } & \multirow[b]{2}{*}{ SED } & \multirow[b]{2}{*}{$P$-value } \\
\hline & Red clover & Ryegrass & & \\
\hline $\mathrm{N}$ intake, $\mathrm{g} / \mathrm{d}$ & 561 & 537 & 16.5 & 0.20 \\
\hline \multicolumn{5}{|l|}{$\mathrm{N}$ output, g/d } \\
\hline Urine & 208 & 189 & 18.4 & 0.34 \\
\hline Feces & 178 & 172 & 10.4 & 0.56 \\
\hline Milk & 161 & 176 & 11.5 & 0.26 \\
\hline $\mathrm{N}$ balance, $\mathrm{g} / \mathrm{d}$ & 14 & 1 & 23.4 & 0.60 \\
\hline $\mathrm{P}$ intake, $\mathrm{g} / \mathrm{d}$ & 76.5 & 75.4 & 1.65 & 0.53 \\
\hline \multicolumn{5}{|l|}{$\mathrm{P}$ output, $\mathrm{g} / \mathrm{d}$} \\
\hline Urine & 2.6 & 2.8 & 0.60 & 0.78 \\
\hline Feces & 39.2 & 39.8 & 1.92 & 0.75 \\
\hline Milk & 33.8 & 38.5 & 3.45 & 0.22 \\
\hline $\mathrm{P}$ balance, $\mathrm{g} / \mathrm{d}$ & 1.1 & -5.7 & 4.72 & 0.20 \\
\hline \multicolumn{5}{|c|}{ Urinary excretion, $\mathrm{mmol} / \mathrm{d}$} \\
\hline Allantoin & 264 & 289 & 53.7 & 0.66 \\
\hline Uric acid & 15 & 23 & 5.0 & 0.15 \\
\hline 3-Methylhistidine & 1.93 & 2.06 & 0.307 & 0.70 \\
\hline Creatinine & 124 & 136 & 19.3 & 0.55 \\
\hline
\end{tabular}

tion has been confirmed in dairy cattle consuming RC silage (Lundh et al., 1990). Circulating concentrations of estrogens correlate with calf birth weight (Erb et al., 1980), which itself correlates positively with postpartum milk yields (Chew et al., 1981). However, there appears to have been no effect of the phytoestrogenic activity of the RC compounds on subsequent lactation performance, although this study was not designed to investigate this effect. However, the small but significant increase in calf birth weight of cows offered the $\mathrm{RC}$ silage may have resulted from a net increase in nutrient supply to the fetus during the last few weeks of gestation. Digestible nutrient intake was lower for the RC-fed cows and therefore plasma nutrient concentrations may have been lower. We hypothesize that this was compensated for by increased uterine blood flow in RC-fed cows; blood flow to the uterus is a key factor limiting fetal growth (Ferrell, 1991) and is stimulated by phytoestrogen activity (Liao et al., 2005; $\mathrm{Xu}$ et al., 2006). The effect of RC silage on partitioning AA away from maternal protein reserves is suggested by the between-treatment differences in longissimus dorsi muscle depth (indicative of whole-body protein content; Gresham et al., 1986). This was lower in early lactation in RC-treated cows, and although there was a large amount of variation in the data, the fitted models indicate that body protein started to decline in RC-fed cows 2 to 3 wk before it did in RG-fed cows.

\section{Lactation Responses}

Dry matter intakes, measured during the first $10 \mathrm{wk}$ of lactation, and apparent whole-tract digestibilities, measured at wk 3 of lactation, were not affected by previous DP treatment. It was therefore not surprising that milk yields were also largely unaffected by DP treatment. Several previous studies also found no differences in lactation performance in mature cows due to use of DP diets that differed more than those used in the current study (VandeHaar et al., 1999; Robinson et al., 2001; Santos et al., 2001).

Minimum longissimus dorsi depths occurred in both groups of cows at about wk 7 of lactation. In a previous study, in which a range of DP diets was offered to dry cows (Moorby et al., 2002b), the pattern of change in longissimus dorsi depth was similar. In that study, cows fed the best diet, composed of RG silage and a protein supplement, also had minimum longissimus dorsi depths at wk 7 of lactation, whereas cows fed poorer quality diets during the DP had minimum depths several weeks earlier. In the current study, $\mathrm{N}$ balance at approximately wk 3 of lactation was unaffected by DP treatment, and both groups of cows were in positive $\mathrm{N}$ balance, but despite this they apparently continued to lose longissimus dorsi depth for another 3 to $4 \mathrm{wk}$. This coincided with continued BW loss, at least for the cows previously offered the RG DP diet, and small changes in BCS (data not shown). This implies continued repartitioning of AA from skeletal muscle to other body tissues, perhaps gut or mammary tissues, even though milk yields peaked (and feed intakes reached a maximum) at approximately wk 4 of lactation. Body weight loss and changes in BCS and longissimus dorsi scan depth were all consistent with previous reports (Jaurena et al., 2005b), but ultimately these changes seem to have been typical for early-lactation dairy 
cows and were unaffected by previous DP treatment. Whole-body $\mathrm{P}$ balance, which was approximately zero at wk 3 of lactation, agrees with previous reports in the literature (Knowlton and Herbein, 2002).

\section{CONCLUSIONS}

Feeding RC silage during the DP had almost no impact on subsequent performance of dairy cows in early lactation compared with RG silage. Nutritionally, the 2 experimental silages were similar, and because DMI in the DP did not differ between treatments, nutrient supplies were affected only by small differences in their DM digestibility. There were some effects of this on BW gain and longissimus dorsi scan depth, but these did not follow into substantial differences in milk yield or composition. There were no differences in $\mathrm{N}$ balance during the DP when the experimental diets were fed or subsequently in early lactation. Dairy cow BW increased until calving, despite a decrease in feed intake, although mobilization of skeletal muscle occurred before calving, indicating repartitioning of AA to other tissues with greater requirements. Although the mineral content of the RC silage fed in this study precluded the need for correction of the dietary cationanion difference, the use of $\mathrm{RC}$ silage as a forage for dry dairy cows offered essentially no benefit over use of a high quality RG silage.

\section{ACKNOWLEDGMENTS}

The authors are grateful for the technical assistance of D. W. R. Davies, J. K. S. Tweed, B. Hauck, and D. Jones (all at the Institute of Grassland and Environmental Research, Aberystwyth, UK). This work was funded by the Department for Environment, Food and Rural Affairs.

\section{REFERENCES}

Agricultural and Food Research Council. 1993. Energy and protein requirements of ruminants. An advisory manual prepared by the AFRC Technical Committee on Responses to Nutrients. CAB International, Wallingford, UK.

Austin, A. R., K. Aston, H. M. Drane, and N. Saba. 1982. The fertility of heifers consuming red-clover silage. Grass Forage Sci. 37:101-106.

Bell, A. W. 1995. Regulation of organic nutrient metabolism during transition from late pregnancy to early lactation. J. Anim. Sci. 73:2804-2819.

Bell, A. W., W. S. Burhans, and T. R. Overton. 2000. Protein nutrition in late pregnancy, maternal protein reserves and lactation performance in dairy cows. Proc. Nutr. Soc. 59:119-126.

Bell, A. W., R. Slepetis, and R. A. Ehrdardt. 1995. Growth and accretion of energy and protein in the gravid uterus during late pregnancy in Holstein cows. J. Dairy Sci. 78:1954-1961.
Bertilsson, J., and M. Murphy. 2003. Effects of feeding clover silages on feed intake, milk production and digestion in dairy cows. Grass Forage Sci. 58:309-322.

Chew, B. P., L. C. Maier, J. K. Hillers, and A. S. Hodgson. 1981 Relationship between calf birth weight and dam's subsequent 200-day and 305-day yields of milk, fat, and total solids in Holsteins. J. Dairy Sci. 64:2401-2408.

Dewhurst, R. J., R. T. Evans, N. D. Scollan, J. M. Moorby, R. J. Merry, and R. J. Wilkins. 2003a. Comparison of grass and legume silages for milk production. 2. In vivo and in sacco evaluations of rumen function. J. Dairy Sci. 86:2612-2621.

Dewhurst, R. J., W. J. Fisher, J. K. S. Tweed, and R. J. Wilkins. 2003b. Comparison of grass and legume silages for milk production. 1. Production responses with different levels of concentrate. J. Dairy Sci. 86:2598-2611.

Dewhurst, R. J., J. M. Moorby, M. S. Dhanoa, R. T. Evans, and W J. Fisher. 2000. Effects of altering energy and protein supply to dairy cows during the dry period. 1. Intake, body condition, and milk production. J. Dairy Sci. 83:1782-1794.

Douglas, G. N., T. R. Overton, H. G. Bateman, H. M. Dann, and J. K. Drackley. 2006. Prepartal plane of nutrition, regardless of dietary energy source, affects periparturient metabolism and dry matter intake in Holstein cows. J. Dairy Sci. 89:2141-2157.

Erb, R. E., B. P. Chew, P. V. Malven, M. F. Damico, C. N. Zamet, and V. F. Colenbrander. 1980. Variables associated with peripartum traits in dairy cows. VII. Hormones, calf traits and subsequent milk yield. J. Anim. Sci. 51:143-152.

Ferrell, C. L. 1991. Maternal and fetal influences on uterine and conceptus development in the cow. 2. Blood flow and nutrient flux. J. Anim. Sci. 69:1954-1965.

González-Ronquillo, M., J. Balcells, A. Belenguer, C. Castrillo, and M. Mota. 2004. A comparison of purine derivatives excretion with conventional methods as indices of microbial yield in dairy cows. J. Dairy Sci. 87:2211-2221.

Gresham, J. D., J. W. Holloway, W. T. Butts, and J. R. McCurley. 1986. Prediction of mature cow carcass composition from live animal measurements. J. Anim. Sci. 63:1041-1048.

Grummer, R. 1995. Impact of changes in organic nutrient metabolism on feeding the transition dairy cow. J. Anim. Sci. 73:28202833.

Holcomb, C. S., H. H. Van Horn, H. H. Head, M. B. Hall, and C. J. Wilcox. 2001. Effects of prepartum dry matter intake and forage percentage on postpartum performance of lactating dairy cows. J. Dairy Sci. 84:2051-2058.

Jaurena, G., J. M. Moorby, and D. R. Davies. 2005a. Efficiency of microbial protein synthesis on red clover and ryegrass silages supplemented with barley by rumen simulation technique (RUSITEC). Anim. Feed Sci. Technol. 118:79-91.

Jaurena, G., J. M. Moorby, W. J. Fisher, and R. Cantet. 2005b. Association of body weight, loin longissimus dorsi and backfat with body condition score in dry and lactating Holstein dairy cows. Anim. Sci. 80:219-223.

Johnson, L. M., J. H. Harrison, and R. E. Riley. 1998. Estimation of the flow of microbial nitrogen to the duodenum using urinary uric acid or allantoin. J. Dairy Sci. 81:2408-2420.

Knowlton, K. F., and J. H. Herbein. 2002. Phosphorus partitioning during early lactation in dairy cows fed diets varying in phosphorus content. J. Dairy Sci. 85:1227-1236.

Lee, M. R. F., R. J. Merry, D. R. Davies, J. M. Moorby, M. O. Humphreys, M. K. Theodorou, J. C. MacRae, and N. D. Scollan. 2003. Effect of increasing availability of water-soluble carbohydrates on in vitro rumen fermentation. Anim. Feed Sci. Technol. 104:59-70.

Liao, W. X., R. R. Magness, and D. B. Chen. 2005. Expression of estrogen receptors-alpha and -beta in the pregnant ovine uterine artery endothelial cells in vivo and in vitro. Biol. Reprod. $72: 530-537$.

Lundh, T. J.-O., H. I. Pettersson, and K. A. Martinsson. 1990. Comparative levels of free and conjugated plant estrogens in blood plasma of sheep and cattle fed estrogenic silage. J. Agric. Food Chem. 38:1530-1534. 
Ministry of Agriculture Fisheries and Food. 1986. The analysis of agricultural materials. 3rd ed. Her Majesty's Stationery Office, London, UK

Moorby, J. M., R. J. Dewhurst, R. T. Evans, and J. L. Danelón. 2006. Effects of dairy cow diet forage proportion on duodenal nutrient supply and urinary pruine derivative excretion. J. Dairy Sci. 89:3552-3562.

Moorby, J. M., R. J. Dewhurst, R. T. Evans, and W. J. Fisher. 2002a. Effects of level of concentrate feeding during the second gestation of Holstein-Friesian dairy cows. 2. Nitrogen balance and plasma metabolites. J. Dairy Sci. 85:178-189.

Moorby, J. M., R. J. Dewhurst, R. T. Evans, and W. J. Fisher. 2002b. Effects of varying the energy and protein supply to dry cows on high-forage systems. Livest. Prod. Sci. 76:125-136.

Moorby, J. M., R. J. Dewhurst, and S. Marsden. 1996. Effect of increasing digestible undegraded protein supply to dairy cows in late gestation on the yield and composition of milk during the subsequent lactation. Anim. Sci. 63:201-213.

Moorby, J. M., R. J. Dewhurst, J. K. S. Tweed, M. S. Dhanoa, and N. F. G. Beck. 2000. Effects of altering the energy and protein supply to dairy cows during the dry period. 2. Metabolic and hormonal responses. J. Dairy Sci. 83:1795-1805.

Moorby, J. M., M. D. Fraser, V. J. Theobald, J. D. Wood, and W. Haresign. 2004. The effect of red clover formononetin content on live-weight gain, carcass characteristics and muscle equol content of finishing lambs. Anim. Sci. 79:303-313.

Mulvany, P. 1977. Dairy cow condition scoring. Paper No. 4468. National Institute for Research in Dairying, Reading, UK.

Payne, R. W., S. A. Harding, D. A. Murray, D. M. Soutar, D. B. Baird, S. J. Welham, A. F. Kane, A. R. Gilmour, R. Thompson, R. Webster, and G. Tunnicliffe Wilson. 2007. GenStat Release 10 Reference Manual, Part 1 Summary. VSN International, Hemel Hempstead, UK.

Robinson, P. H., J. M. Moorby, M. Arana, R. Hinders, T. Graham, L. Castelanelli, and N. Barney. 2001. Influence of close-up dry period protein supplementation on productive and reproductive performance of Holstein cows in their subsequent lactation. J. Dairy Sci. 84:2273-2283.

Santos, J. E. P., E. J. DePeters, P. W. Jardon, and J. T. Huber. 2001. Effect of prepartum dietary protein level on performance of primigravid and multiparous Holstein dairy cows. J. Dairy Sci. $84: 213-224$.

Tesfa, A. T., M. Tuori, L. Syrjala-Qvist, R. Poso, H. Saloniemi, K. Heinonen, K Kivilahti, T. Saukko, and L. A. Lindberg. 1999. The influence of dry period feeding on liver fat and postpartum performance of dairy cows. Anim. Feed Sci. Technol. 76:275295.

Thomas, C., K. Aston, and S. R. Daley. 1985. Milk production from silage. 3. A comparison of red clover with grass silage. Anim. Prod. 41:21-31.

Thomson, D. J. 1975. The effect of feeding red clover conserved by drying or ensiling on reproduction in the ewe. J. Br. Grassl. Soc. $30: 149-152$

Tucker, W. B., J. F. Hogue, D. F. Waterman, T. S. Swenson, Z. Xin, R. W. Hemken, J. A. Jackson, G. D. Adams, and L. J. Spicer. 1992 Sulfur should be included when calculating the dietary cationanion balance of diets for lactating dairy cows. Pages 141-150 in Animal Science Research Report, Oklahoma Research Station.

Van Saun, R. J., S. C. Idleman, and C. J. Sniffen. 1993. Effect of undegradable protein amount fed prepartum on postpartum production in first lactation Holstein cows. J. Dairy Sci. 76:236244.

VandeHaar, M. J., G. Yousif, B. K. Sharma, T. H. Herdt, R. S. Emery, M. S. Allen, and J. S. Liesman. 1999. Effect of energy and protein density of prepartum diets on fat and protein metabolism of dairy cattle in the periparturient period. J. Dairy Sci. 82:1282-1295.

$\mathrm{Xu}$, Y. Y., C. Yang, and S. N. Li. 2006. Effects of genistein on angiotensin-converting enzyme in rats. Life Sci. 79:828-837. 